\title{
Communication of flagship species in conservation: lessons from invasive management projects
}

Article

Accepted Version

Melero, Y. (2017) Communication of flagship species in conservation: lessons from invasive management projects. Biodiversity and Conservation, 26 (12). pp. 2973-2978. ISSN 1572-9710 doi: https://doi.org/10.1007/s10531-017-1389-6 Available at https://centaur.reading.ac.uk/83098/

It is advisable to refer to the publisher's version if you intend to cite from the work. See Guidance on citing.

To link to this article DOI: http://dx.doi.org/10.1007/s10531-017-1389-6

Publisher: Springer

All outputs in CentAUR are protected by Intellectual Property Rights law, including copyright law. Copyright and IPR is retained by the creators or other copyright holders. Terms and conditions for use of this material are defined in the End User Agreement.

$\underline{\text { www.reading.ac.uk/centaur }}$ 
Central Archive at the University of Reading

Reading's research outputs online 
1 Communication of flagship species in conservation: lessons from invasive management

2 projects

3 Yolanda Melero ${ }^{1}$

$4 \quad{ }^{1}$ CREAF, Cerdanyola del Vallés 08193, Spain

5 E mail: y.melero@ creaf.uab.cat, Phone: +34 935814677

7 Running title: Communication with the public in conservation

8 Keywords: Communication, Flagship species, Invasive species, Management, Volunteers

9 Type of article: Policy Perspective

10 Number of words in abstract: 127

11 Total number of words (including abstract but excluding references): 1903

12 Number of references: 30

13

14 Abstract

15 With the increase of public awareness and involvement in conservational projects, flagship

16 species have become a common tool to appeal to people's motivations. Yet, the effectiveness

17 of these species depends on a proper communication of their conservational importance.

18 Using two projects aiming to control the invasive species American mink, I illustrate how

19 communication can positively or negatively impact on succeeding at involving the public; and

20 consequently on the projects. The Scottish mink initiative project managed to increase the

21 number of volunteers involved by selecting flagship species and their communication adapted

22 to the public needs. Meanwhile, in the Spanish project, while no volunteers are yet involved,

23 there has been an increase of public awareness via using the European mink as native flagship

24 species. However, as its nativeness reaming unconfirmed I suggest there is a high risk of

25 potential miss-communication with the public that can negatively impact on their perception. 
27 Public awareness and participation in management projects aiming to safeguard biodiversity

28 have become key to bring support, funds and success. The reason behind people awareness or

29 involvement in conservation projects is a complex compound of personal, social and

30 environmental factors (Smith and Sutton 2008; Beirne and Lambin 2013); among which

31 empathy, self and community benefit, and sense of responsibility about biodiversity loss

32 have been reported as key motivational drivers (Hart \& Larson 2014; Verissimo et al. 2011).

33 To promote public awareness and participation, scientists and managers need to connect these

34 motivational drivers with the objective behind management. Confronted with the difficulty of

35 dealing with numerous personalized interactions between them and the network of citizens,

36 generalized motivational arguments such as the protection of flagship species are of common

37 use (Caro 2010).

39 The idea behind the use of flagship species is that management focused on one or a few 40 species will benefit an entire ecosystem. Thus, frequently the selection of these species is 41 based on ecological factors including (but not exclusively) their role in the ecosystem or on 42 their vulnerable status (Simberloff 1998; Kalinkat et al. 2016). Besides, among the potential 43 set of species those most charismatic and appealing to the target audience are frequently 44 selected (Verissimo et al. 2011; Veríssimo et al. 2014) because they better enhance public 45 awareness and participation (Smith and Sutton 2008). Yet, the effectiveness at driving people 46 motivation highly depends on properly communicating the reasons behind this selection. To 47 make projects and the ecological concepts accessible to a wide audience of citizens, 48 communication is sometimes simplified. However, citizen knowledge is an important 49 component of their involvement and resilience (Hou 2016), and therefore transmitting proper 50 information can be crucial for the long term viability of the project. Where scientist and 51 managers fail at proper communicating with citizens the latest may lose awareness, and if 52 involved in participation, their motivation and commitment, potentially dropping out from the 53 project. 
55 The appropriate selection of flagship species and the communication strategy is especially

56 important in projects aiming to reduce or eradicate invasive animal species via removal since

57 this type of project is generally less attractive by the general public than those dealing directly

58 with species protection; yet, the support and, frequently, involvement via volunteer

59 participation in projects managing invasive species is essential for assuring success at a

60 significant spatial scale, especially when leading with highly dispersive species (e.g., Delaney

61 et al. 2008; Oliver et al. 2016).

63 Here I illustrate the importance of the selection of the flagship species and of the proper

64 communication of the reasons behind their selection for the management of invasive species.

65 To do so I use the successful example of a management project aiming to control the invasive

66 American mink (Neovison vison) in Scotland based on volunteer involvement. Then, I use the

67 example of the Spanish management project, which recently started to work on public

68 awareness via the use of (unconfirmed native) flagships species and the potential future

69 caveats this could face. I've been actively involved as project scientist in both and, in the first

70 case, also as volunteer. I explain here their respective communication strategies and how they

71 affected or may affect public awareness and participation.

\section{The American mink control in Scotland}

74 The American mink control in Scotland, one of the largest mammal control project in Europe, 75 was initiated in 2006 centered on the Cairngorms National Park covering 3,800 km² (CNP $7657^{\circ} 0^{\prime} \mathrm{N} 3^{\circ} 3^{\prime} \mathrm{W}$; NE Scotland) and gradually expanded over time to ca. 20,000 $\mathrm{km}^{2}$ in 2012 77 supported by ca. 400 volunteers (Bryce et al. 2011). Starting with 186 volunteers involved 78 during the first years of the project, the number raised to 450 ca. in 2014 , mostly composed of 79 local residents, non professional naturalists and wildlife professionals; which have been key 80 in the success of the project (Beirne \& Lambin, 2013; Bryce et al. 2011). 
82 The project started using the water vole (Arvicola terrestris) as flagship species to protect

83 native species affected by American mink. Water voles are key stones in the ecosystem

84 functioning but in the UK they suffered near catastrophic declines of over $80 \%$ partly

85 attributed the predation to mink predation (Aars et al. 2001). The selection of the water vole

86 as kick start flagship species for the project primary responded to ecological factors given its

87 declining status and its role in ecosystem functioning (Aars et al. 2001; Bryce 2006). Besides,

88 the species has a charismatic value within the general public in the UK, since it has been

89 symbolised for generations of children by the character Ratty (though actually a water vole)

90 in Kenneth Grahame's tale "The Wind in the Willows" (1908); which provides a cultural

91 attachment and familiarity to species, traits positively related to citizens' motivation (Bowen-

92 Jones and Entwistle 2002; Jepson and Barua 2015). When expanding, the project evolved to

93 incorporate other flagship species depending on the public interests in the area. For example,

94 using native birds in the coastal West Scotland and salmonids in the East because their

95 ecological and economical value in nature-based and fishing-based tourism (e.g., Fraser et al.

96 2014).

97

98 Communication about the species and the project itself, has been focused on the ecological,

99 economical and cultural value of the flagship species; recurrently done using different set of

100 media, from one to one interactions with citizens to public talks, newsletters, automated

101 feedback to those citizens being volunteers (e.g., Tintarev et al. 2012) and local and national

102 press and TV news (e.g., http://www.bbc.com/news/science-environment-19503827).

103

104 The success of the control project at reducing American mink densities (e.g., Melero et al.,

105 2015; Oliver et al., 2016), the ability to adapt the project to the different public needs and a

106 customised and recurrent communication helped at ensuring the public support ad well as the

107 recruitment and the long term retention of volunteers (Beirne \& Lambin 2013; Fraser et al.

108 2014).

109 
111 Most of the regional and national scale American mink control projects in Spain started in the

112 decade of the 1990s with little success in controlling or reducing the species (e.g., Melero et

113 al. 2010). The wide distribution of the species, with most populations still expanding, and the

114 continuous and drastic reductions in funding have limited the successful control of mink

115 populations. Besides, the public awareness has been for long poor and the participation close

116 to null. (e.g., ca. $<5$ volunteers in the population at NE Spain in $2007,>20000 \mathrm{~km}^{2}$; Melero

117 2007).

118

119 Notwithstanding, during the last years project scientist and managers have worked on

120 increasing public awareness. In NW Spain, awareness is raised towards the impacted breeding

121 birds of special conservational and touristic interest (Velando \& Munilla, 2008; Barros et al.

122 2016). In central and NE Spain, the American mink poses a threat to the endangered

123 Pyrenean desman (Galemys pirenaicus) but it is rarely used as flagship species because it is

124 yet a poorly known species between the general public despite the scientific recognition of its

125 high value for biodiversity and evolution due to its relic and narrow endemic character

126 (Nowak 1999). The biggest part of the communication strategy, both regional (North Spain)

127 and national, relies on the effect of the American mink on its counterpart the European mink

128 (Mustela lutreola).

130 As in the case of the Scottish project, communication is done using different media from

131 public talks (e.g. in civic centers and schools) to dissemination of media videos in the social

132 media (see e.g. https://youtu.be/lkPXLmDSBHs) and local or national news. There are not

133 recurrent newsletters but there is an active involvement with the local communities via public

134 activities (see eg. http://lifelutreolaspain.com/en/education-awareness). The main message of

135 this communication is the need to conserve the native European mink from the introduced

136 American mink. Overall, it seems communication is effectively increasing public awareness

137 on the presence and risks of the American mink related to the conservational status of the 
138 European mink. However, this message confronts with the current ongoing debate on the

139 nativeness of the European mink population in the area among scientist (Clavero, 2015;

140 Clavero, 2014; Zuberogoitia et al. 2016). Defenders of the species' nativeness claim that the

141 populations in the is the result of constrictions of its native distribution who left the

142 population on the western France and northern Spain isolated (e.g. Zuberogoitia et al. 2016);

143 but the late detection of the species (1831 and 1955 for France and Spain; Saint-Girons 1994)

144 and its low genetic variability compared to the populations in Russia and the Danube points to

145 human mediated introductions (Michaux et al. 2005). Without entering in this debate but

146 aware of its existence, a logical concern follows in relation to the communication strategy:

147 What would happen if the human mediated introduction hypothesis was eventually

148 confirmed?

150 At least two processes will be directly impacted, the motivational reason for its conservation

151 and the public perception. In the first case, scientist, managers and conservationists would

152 need to decide whether continuing working towards the conservation of the population or

153 shift towards its control based on its introduced non native status. This last, in my opinion, is

154 unlikely to occur since the critically endangered situation of the species and its endemic

155 character in Europe (Maran et al. 2016) makes any remaining population worth to conserve

156 for the global benefit of the species and biodiversity. Therefore, the motivational argument

157 for the conservation of the species in Spain (and France) would need to change towards

158 safeguarding an endangered species rather than because its nativeness. However, the impact

159 on the public perception might be harder to shift after public awareness linked to the

160 conservation importance of the species as a native facing the invasion of the introduced

161 American.

163 Under the face of this possibility one may wonder why communication on the European mink

164 as a flagship species is not generally focus on its overall importance as endangered endemic

165 species in Europe, instead of its unconfirmed nativeness; and why communication is based on 
this species only rather than expanding it to other species of confirmed nativeness and interest

167 such as the Pyrenean desman. Even supporters of its nativeness could consider to follow this

168 "conservative approach" when communicating given the impact on public perception that

169 could occur if the introduction is confirmed.

170

\section{Conclusions}

172 The two projects presented here illustrated how similar strategies on communicating the

173 selection of flagship species may have different impact on people's perception and interest on

174 management initiatives. Beyond potential cultural differences, the success of volunteers'

175 involvement in the Scottish project is linked to the success of its strategy to appeal to the

176 public interest by adaptive the selection and communication of flagships species to their

177 background. Meanwhile, the Spanish project is mostly focused on the importance of the

178 nativeness of a single species, rather than using a wider range of available species of interest

179 or fully explaining the controversy behind this selection. As such, while public awareness is

180 increasing, there is a high risk of people's rejection if the main message (the species

181 nativeness) is confirmed to be wrong.

\section{References}

Aars J, Lambin X, Denny R, Griffin AC (2001) Water vole in the Scottish uplands: distribution patterns of disturbed and pristine populations ahead and behind the American mink invasion front. . Anim Conserv 4:187-194. doi: doi:10.1017/S1367943001001226

Beirne C, Lambin X (2013) Understanding the Determinants of Volunteer Retention Through Capture-Recapture Analysis: Answering Social Science Questions Using a Wildlife Ecology Toolkit. Conserv Lett 6:391-401. doi: 10.1111/conl.12023

Bowen-Jones E, Entwistle A (2002) Identifying appropriate flagship species: the importance of culture and local contexts. Oryx 36:189-195. doi: 10.1017/S0030605302000261

Bryce R, Oliver MK, Davies L, et al (2011) Turning back the tide of American mink invasion 
at an unprecedented scale through community participation and adaptive management.

Biol Conserv 144:575-583. doi: 10.1016/j.biocon.2010.10.013

196 Bryce RL (2006) The ecosystem engineering and trophic effects of the water vole : species loss and ecosystem processes. University of Aberdeen

Caro T (2010) Conservation by proxy: indicator, umbrella, keystone, flagship, and other surrogate species. Island Press, Washington, D.C.

Clavero M (2015) Non-Native species as conservation priorities: response to Díez-León et al. Conserv Biol. doi: 10.1111/cobi.12524

Clavero M (2014) Shifting Baselines and the Conservation of Non-Native Species. Conserv Biol n/a-n/a. doi: 10.1111/cobi.12266

Delaney DG, Sperling CD, Adams CS, Leung B (2008) Marine invasive species: validation of citizen science and implications for national monitoring networks. Biol Invasions 10:117-128. doi: 10.1007/s10530-007-9114-0

Fraser EJ, Macdonald DW, Bryce R, Lambin X (2014) Controlling invasive species by

Garcia P (2012) Situación actual del desmán ibérico, Galemys pyrenaicus (E. Geoffroy Saint Hilaire, 1811), en la provincia de Salamanca. University of Salamanca

213 Grahame K (1908) The Wind in the Willows.

214 Hart PS, Larson BMH (2014) Communicating About Invasive Species: How “Driver” and “Passenger" Models Influence Public Willingness to Take Action. Conserv Lett 7:545-

217 Hou D (2016) Divergence in stakeholder perception of sustainable remediation. Sustain Sci. doi: $10.1007 / \mathrm{s} 11625-015-0346-0$

Jepson P, Barua M (2015) A Theory of Flagship Species Action. Conserv Soc 13:95. doi: $10.4103 / 0972-4923.161228$

221 Kalinkat G, Cabral JS, Darwall W, et al (2016) Flagship umbrella species needed for the 

conservation of overlooked aquatic biodiversity. Conserv Biol. doi: 10.1111/cobi.12813

Manfredo MJ, Teel TL, Dietsch AM (2016) Implications of human value shift and persistence for biodiversity conservation. Conserv Biol 30:287-296. doi: 10.1111/cobi.12619

Maran T, Skumatov D, Gomez A, et al (2016) Mustela lutreola. The IUCN Red List of Threatened Species 2016.

Melero Y, Palazón S, Bonesi L, Gosàlbez J (2010) Relative abundance of culled and not culled American mink populations in northeast Spain and their potential distribution: are

Melero Y, Robinson E, Lambin X (2015) Density- and age-dependent reproduction partially compensates culling efforts of invasive non-native American mink. Biol Invasions 17:2645-2657. doi: 10.1007/s10530-015-0902-7

Michaux JR, Hardy OJ, Justy F, et al (2005) Conservation genetics and population history of the threatened European mink Mustela lutreola, with an emphasis on the west European population. Mol Ecol 14:2373-2388. doi: 10.1111/j.1365-294X.2005.02597.x

Nowak RM (1999) Walker's mammals of the world. The Johns Hopkins University Press,

Oliver M, Luque-Larena JJ, Lambin X (2009) Do rabbits eat voles? Apparent competition, habitat heterogeneity and large-scale coexistence under mink predation. Ecol Lett 12:1201-1209. doi: 10.1111/j.1461-0248.2009.01375.x

Oliver MK, Piertney SB, Zalewski A, et al (2016) The compensatory potential of increased

Saint-Girons MC (1994) Wild mink (Mustela lutreola) in Europe. Nature and environment 54. Strassbourg

Simberloff D (1998) Flagships, umbrellas, and keystones: Is single-species management passé in the landscape era? Biol Conserv 83:247-257. doi: 10.1016/S0006$3207(97) 00081-5$ 
250 Smith AM, Sutton SG (2008) The Role of a Flagship Species in the Formation of

251 Conservation Intentions. Hum Dimens Wildl 13:127-140. doi:

$252 \quad 10.1080 / 10871200701883408$

253 Tintarev N, Melero Y, Sripada S, et al (2012) MinkApp: Generating Spatio-temporal

254 Summaries for Nature Conservation Volunteers. In: Proceedings of the International

255 Conference of Natural Language generation. Association for Computational Linguistics,

$256 \quad$ Utica, Illinois, pp 17-21

257 Velando A, Munilla I (2008) Plan de Conservación del Cormorán moñudo en el Parque

$258 \quad$ Nacional de las Islas Atlánticas. Vigo

259 Veríssimo D, Fraser I, Girão W, et al (2014) Evaluating Conservation Flagships and Flagship

$260 \quad$ Fleets. Conserv Lett 7:263-270. doi: 10.1111/conl.12070

261 Verissimo D, MacMillan DC, Smith RJ (2011) Toward a systematic approach for identifying

262 conservation flagships. Conserv Lett 4:1-8. doi: 10.1111/j.1755-263X.2010.00151.x

263 Zuberogoitia I, Põdra M, Palazón S, et al (2016) Misleading interpretation of shifting baseline

264 syndrome in the conservation of European mink. Biodivers Conserv 25:1795-1800. doi:

$265 \quad 10.1007 / \mathrm{s} 10531-016-1156-0$

266 